\title{
Municipal Governance Reforms In Haryana: A Review
}

\author{
Ranjit Singh $^{1}$, Vinod Kumar ${ }^{2}$ \\ ${ }^{1}$ Research Scholar, Panjab University, Chandigarh (India). \\ ${ }^{2}$ Assistant Professor (Guest Faculty), Department of Evening Studies, Panjab University, Chandigarh (India).
}

\begin{abstract}
Indian local Government has evolved over time. Various attempts have been made in this direction by the Union and State government to strengthen the urban local government. Authors have made an attempt to highlight the initiatives of Indian Government in line of reform in Municipal Government such as $74^{\text {th }}$ constitutional amendment act which have provided a constitutional recognisation to Municipal government and Jawaharlal Nehru National Urban Renewal Mission (JNNURM). Authors have also discussed the state government initiatives in this regard. In addition to this they have highlighted the problems of Municipal Government such as finance, immigration and made some suggestion to cure them.
\end{abstract}

Key Words: Urban Local Government, $74^{\text {th }}$ Constitutional Amendment Act, Haryana

\section{Introduction}

Urbanization is an emerging phenomenon in the developing countries, going by the present trends of urbanization more than half of the world population would be living in urban areas by the turn of this century ${ }^{1}$. As per 2001 census, out of total 1.02 billion population of India, the urban population is about 285 million, which is $27.8 \%$ of total population. The rate of urban growth in the country is very high as compared to developed countries and the large cities are becoming large mostly due to continuous migration of population to these cities. Based on the population forecast made by registrar general, census operation, Government of India, the urban population is expected to reach 433 million by 2012, while the total population may reach 1340 million. Thus, the level of urbanization in the country in the year 2021 is expected to be about $32 \%$. By way of the increase in urban population, urban centers are at risk of numerous problems. These problems are associated with physical, infrastructural, environmental and socio-economic. Thus, keeping in view a systematic and planned policy for urban development is needed. ${ }^{2}$ The present study would focus on the contribution of central Government in municipal reforms and role of urban development programs and policies towards urban development

Initiative of central government for Municipal Government

In recognition of Municipal Government, the Government of India attempted several reforms such as enactment of model municipal law, Jawaharlal Nehru National Urban Renewal Mission and the $74^{\text {th }}$ Constitutional Amendment Act (CAA). Before this amendment, Municipal bodies were established under various law passed by the legislatures or executive orders of the government. The structure, function and powers of these bodies were different from state to state in India. A number of problems confronting local governments began to emerge, such as excessive official control, narrow franchise, inadequate resources, lack of education and training, shortage of capable and committed persons, and inadequate control of local bodies over services. A need was felt to strengthen the local government institutions that would look after the day-to-day civic affairs in an efficient manner. A number of steps were taken from time to time in an attempt to reform local governments. In response to these immediate reforms were made to construct the municipal government responsive, transparent inclusive and capable.

\section{$74^{\text {th }}$ Constitutional Amendment Act (CAA)}

The Constitution (74th Amendment) Act, 1992 is a landmark initiative of the Government of India to strengthen local self-government in cities and towns. It is built upon the premise that all 'power' in a democracy rightfully belongs to 'the, people'. The mandate of the Municipalities is to undertake the tasks of planning for 'economic development and social justice' and implement city/town development plans. This role is much larger than what is traditionally perceived of them as the providers of 'services'. The 74th Amendment Act aims transformation in the 'structure' of urban service delivery.

$74^{\text {th }}$ CAA has introduced some changes in Municipal Government. (i) Uniformity in the organizational structure of the urban local bodies throughout the country into three tier system - Municipal Corporation for

\footnotetext{
${ }^{1}$ H. M. Mishra, Rebounding Urban Development through Urban Renewal and Infrastructure Development, Nagarlok, July-September, 2007,Vol.39,13-14.

${ }^{2}$ Report of the working group of the urban development for eleventh five year plan (2007-2012), P.1. 
large city, Municipal Council small cities and towns and Nagar panchayats for transition area from rural to urban (ii) The constitution of Wards Committees for a group of wards is mandatory prescribed for cities with more than 3 lakh population, which no bar for the constitution of such Committees in cities/towns with lesser population, with a view of taking to take municipal governance closer to the people. (iii) Reservations for scheduled Castes (SCs), Scheduled Tribes (STs) and women in municipal councils. The seats reserved for SCs and STs are to be in proportion to their share in population of the respective cities/towns. (iv) The composition, power and function of the state finance commission to reduce the financial dependence of the ULB's on the state government and redefine the state-local fiscal relations. (vi) District Planning Committees (DPCs) to consolidate the plans prepared by the Panchayats and the Municipalities in the district as a whole. (vii) Metropolitan Planning Committees (MPCs) to prepare draft development plan for the Metropolitan area as a whole.

The $12^{\text {th }}$ schedule containing a suggestive list of 18 subjects that transferred to the Municipal government by the state legislature by law.

The subject included in the $12^{\text {th }}$ schedule (Article $243-\mathrm{W}$ ) are-

1. Urban planning includes town planning.

2. Regulation of land use and construction of building.

3. Roads and bridges.

4. Planning for economics and social development.

5. Water supply for domestic, industrial, and commercial purposes.

6. Public health, sanitation conservancy, and commercial purposes.

7. Fire services.

8. Urban forestry, protection of the environment and promotion of ecological aspect.

9. Safeguarding the interests of weaker sections of society, including the handicapped and mentally retarded.

10. Slum improvement and up gradation.

11. Urban poverty alleviation.

12. Provision of urban amenities and facilities such as parks, gardens, playground.

13. Promotion of cultural, education and aesthetic aspects.

14. Burials and burial grounds; cremations, cremation grounds electric crematoriums.

15. Cattle ponds; prevention of cruelty to animals.

16. Vital statistics including registration of birth and deaths.

17. Public amenities, including street lighting, parking lots, bus stop, and public conveniences.

18. Regulation of slaughterhouses and tanneries. ${ }^{3}$

\section{Jawaharlal Nehru National Urban Renewal Mission (JNNURM)}

The government of India launched a time bound urban renewal program in 2005 with an aim to fast track planned development of identified sixty three cities in India. The project focused on efficiency in urban infrastructure and service delivery mechanisms, community participation, and accountability of ULBs towards citizens. The main objectives of the JNNURM are; Focused attention to integrated development of infrastructure services in cities; Establishment of linkages between asset-creation and asset-management through a slew of reforms for long-term project sustainability; Ensuring adequate funds to meet the deficiencies in urban infrastructural services; Planned development of identified cities; Scale-up delivery of civic amenities and provision of utilities with emphasis on universal access to the urban poor; Special focus on urban renewal programmes for the old city areas to reduce congestion; and Provision of basic services to the urban poor, improved housing, water supply and sanitation, and ensuring delivery of other existing universal services of the government for education, health and social security ${ }^{4}$. This plan is different from other earlier programmes as it encourages inclusive development. The JNNURM envisages some obligatory reforms at the National, State and ULB levels. Some of the obligatory reforms given at the ULB/ parastatal level may be point out here as follow:

- Adoption of modern accrual-based double entry system of accounting in ULBs and parastatal agencies for better financial management and transparency.

- Introduction of a system of e-governance using IT applications, such as GIS and MIS for various services provided by ULBs and parastatal agencies. So that citizens can get transparent and quick services.

- Reform in levy, collection and administration of property tax with GIS. It is a major source of revenue for ULBs and GIS make arrangements for its effective implementation so that collection efficiency is increased.

- Internal allocating within local bodies, allocating of funds in budgets for basic services to the urban poor.

\footnotetext{
${ }^{3}$ S. Mehaswari, Local Government in India (Lakshmi Narain Agarwal, Educational Publishers, Hospital road, Agra-3, pp.184-185, 2002)

${ }^{4}$ http://jnnurm.nic.in/wp-content/uploads/2011/01/UIGOverview.pdf Accessed on 11 September 2012 
- Provision of basic services to the urban poor, improved housing, water supply and sanitation. Delivery of other existing universal services of the government for education, health and social security is ensured.

Model Municipal Law (MML)

Model Municipal Law (MML) constituted in 2003, it is an important initiative of the government of India and its objectives are to implement in totality the provisions of the $74^{\text {th }}$ amendment for the empowerment of Urban Local Bodies (ULBs), and provide legislative framework for implementation of the Ministry's urban sector reforms agenda. This initiative is expected to create an environment in which ULBs can play their role more effectively and ensure better service delivery. Some salient features of the Model Municipal Law are briefly discussed below.

- A unified law for three levels of ULBs.

- Executive power of an ULB to be exercised by the Empowered Standing Committee.

- Municipal fund with separate accounts for various services.

- Indirect election of Mayor or Chairperson with five years term.

- Constitution of Wards and Ward Committees.

- State Level Municipal Establishment Audit Commission to review the staff status ${ }^{5}$

\section{Initiative of Haryana Government}

Government of India has taken several initiatives towards good urban governance with a view to making urban local bodies as self-sustaining viable entities of local self government. In tune with national developments, Haryana governments have also taken various innovative steps to promote Municipal Corporation. Haryana is a landlocked state in northern India ${ }^{6}$. The state is divided into four divisions for administrative purpose - Ambala Division, Rohtak Division, Gurgaon Division and Hisar Division. There are 21 districts, 47 sub-divisions, 67 tehsils, 45 sub-tehsils and 116 blocks. Haryana has a total of 81 cities and towns and 6,759 villages. The administrative division of Haryana (Table no. 1)

Table-1

\begin{tabular}{|l|l|l|l|}
\hline \multicolumn{5}{|c|}{ Districts } \\
\hline \multicolumn{1}{|c|}{ Ambala Division } & \multicolumn{1}{|c|}{ Gurgaon Division } & \multicolumn{1}{|c|}{ Hisar Division } & Rohtak Division \\
\hline Ambala District & Faridabad District & Bhiwani District & Jhajjar District \\
\hline Kaithal District & Palwal District & Fatehabad District & Karnal District \\
\hline Kurukshetra District & Gurgaon District & Hisar District & Panipat District \\
\hline Panchkula District & Mahendragarh District & Jind District & Rohatak District \\
\hline $\begin{array}{l}\text { Yamuna Nagar } \\
\text { District }\end{array}$ & Mewat District & Sirsa District & Sonipat District \\
\hline & & & \\
\hline
\end{tabular}

Sources: haryanaonline.nic

\section{Haryana Urban Development Authority (HUDA)}

Haryana Urban Development Authority (HUDA), a statutory body of Government of Haryana. HUDA is carved out of the erstwhile Department of Urban Estates to overcome the difficulties in development and implementation by different departments and to achieve the speedy development of urbanization in Haryana. HUDA has so far setup 27 urban estates throughout the state of Haryana. HUDA takes up all the developmental activities by itself and provide various facilities in the urban estates. The main functions of HUDA are: To promote and secure development of urban areas with the power to acquire, sell and dispose of property; To acquire, develop and dispose land for residential, industrial and commercial purposes; To make available

\footnotetext{
${ }^{5}$ M.P. Mathur, Model Municipal law to Improve Reform Process, Quarterly Newslatter of the National Institute of Urban Affairs, Vol. 6, 2003 No.4, 1-12.

${ }^{6} \mathrm{http}: / / \mathrm{www} \cdot h a r y a n a o n l i n e$
} 
developed land to Haryana Housing Board and other bodies for providing houses to economically weaker sections of the society and to undertake building works.

\section{Use of Information Communication Technology in Municipal Corporation}

The government of Haryana has outlined its Information Technology (IT) policy. This policy seeks a deep impact initiative by the state Government in encouraging replacement of traditional delivery system of Municipal public services by IT driven system of governance that works better, cost less and is capable of serving the citizen's needs with ease. Haryana has an IT vision and a dream that all citizens should access government and private sector services from their own villages and towns ${ }^{7}$. At present, the following Municipal services have been integrated and offered from Common Services Centers (CSCs) for the people Forms \& Procedures; Birth \& Death Certificate of Urban Areas; House Tax Collection, Billing and Query; Social Welfare Schemes Application acceptance; Caste \& Residence Certificate Issuing; Passport Application collection; Arms Licence; License: Permanent Driving License/Duplicate/Renewal; Vehicle Registration Certificate. The Government of Haryana is planning to provide more municipal services to the citizens. In brief it can be said that e-governance initiatives strengthens accountability, increase transparency, improve efficiency and reduce corruption. E-governance is transforming organizations by introducing ICT in their governance system and breaking down organizational boundaries and facilitating democratic processes. ${ }^{8}$

\section{Haryana Urban Infrastructural Development Board}

The Government of Haryana has constituted Haryana Urban Infrastructural Development Board (HUIDB) in April, 2002 with a view to raise resources for provision and up-gradation of Urban Infrastructure in all municipalities; Training facilities in Urban Management and Human resources; Development of Municipalities and Urban Development Department by organizing Seminars, workshops and conferences on Urban management; Coordinating, planning and implementing the approved schemes/projects of the municipalities and The Haryana Urban Infrastructural Development Board has also been declared nodal agency for implementation of Jawaharlal Nehru National Urban Renewal Mission (JNNURM) and Urban Infrastructure Development Scheme for Small \& Medium Towns (UIDSSMT).

\section{Urban infrastructure Development Scheme for Small \& Medium Towns (UIDSSMT)}

Urban infrastructure Development Scheme for Small \& Medium Towns (UIDSSMT) is another initiative of government of Haryana in line of Municipal reform. It aims at improvement in urban infrastructure in towns and cities in a planned manner. The scheme will apply to all cities/towns as per 2001 census, excepting cities/towns covered under Jawaharlal Nehru National Urban Renewal Mission (JNNURM). The objectives of the scheme are to: Improve infrastructural facilities and help create durable public assets and quality oriented services in cities \& towns; Enhance public-private-partnership in infrastructural development and Promote planned integrated development of towns and cities.

\section{Conclusion and suggestion}

This study has shown that the form of urban local governments in India has changed over time. Subsequently, numerous initiatives have been undertaken at national and state level to construct more and more autonomous, participatory, representative, transparent, accountable and dynamic municipalities. Important among these are the enactment of a set of constitutional provisions, implementation of numerous urban development programs and adoption of various innovative practices. Although, municipalities continue to be governed by the respective State legislatures, it has been made mandatory for the State governments to revise their municipal laws in accordance with the recent Constitutional provisions. Even then, the Municipal Government has been facing numerous problems; the financial condition of Municipal Government is not good enough. Municipal Corporation has very limited sources of revenue. They get grants from State or Central Government. Therefore, centre/state government should provide adequate funds and allocate sufficient power for tax collection. It is also necessary that the Municipal Government should be free from political pressure. This is so because if the local bodies belong to the ruling party, they are dictated by the party. If they do not, they are not allowed to function effectively. An effective policy should be made to remove this evil. The process of urbanization has added more problems to Municipal government such as increase of slums, violence, unrest, crime and many other social evils. It is also a vital concern in present scenario, authority must concentrate on it. In nutshell, it may be concluded the several legal reforms are yet to be implemented throughout the country, so that the existing problems of Municipal Government can be cured.

\footnotetext{
${ }^{7}$ www.hartron.org

${ }^{8}$ Y Y. Pardhasuradhi and Ravinder Kaur, Public Private Partnerships and E-Governance: An Indian Experience, Indian Journal of Public Administration, Vol. LIV, No. 3, July-September, 2008, 550-565.
} 


\section{References}

[1] H. M. Mishra, Rebounding Urban Development through Urban Renewal and Infrastructure Development, Nagarlok, JulySeptember, 2007,Vol.39,13-14.

[2] Report of the working group of the urban development for eleventh five year plan (2007-2012), P.1.

[3] S. Mehaswari, Local Government in India (Lakshmi Narain Agarwal, Educational Publishers, Hospital road, Agra-3, pp.184-185, 2002)

[4] http://jnnurm.nic.in/wp-content/uploads/2011/01/UIGOverview.pdf Accessed on 11 September 2012

[5] M.P. Mathur, Model Municipal law to Improve Reform Process, Quarterly Newslatter of the National Institute of Urban Affairs, Vol. 6, 2003 No.4, 1-12.

[6] http://www.haryanaonline Accessed on 14 September 2012

[7] Www.hartron.org Accessed on 11 September 2012

[8] Y. Pardhasuradhi and Ravinder Kaur, Public Private Partnerships and E-Governance: An Indian Experience, Indian Journal of Public Administration, Vol. LIV, No. 3, July-September, 2008, 550-565. 